\title{
ESTIMATION AND CORRELATION ANALYSIS OF HEAVY METALS OF SOME WELL WATER IN ZAKHO CITY, IRAQ
}

\author{
Haydar A. Mohammad Salim a, ${ }^{\text {, }}$, Hasan Ramadhan Abdo ${ }^{\text {b }}$, Faris Jameel Buni ${ }^{\text {, }}$, Idrees Majeed Kareem ${ }^{\text {b }}$, Mothanna Abdula \\ Najeeb $^{\mathrm{b}}$, and Bafreen Ahmad Hussen ${ }^{\mathrm{b}}$ \\ a Dept. of Chemistry, Faculty of Science, University of Zakho, Zakho, Kurdistan Region, Iraq - haydar.kovly@ gmail.com \\ ${ }^{\mathrm{b}}$ Board of Protecting and Improving Environment, Duhok Environment Office, Duhok, Kurdistan Region, Iraq
}

\begin{abstract}
:
This study was carried out to examine the concentrations of major heavy metals in fifteen different well water in Zakho City, Kurdistan Region, Iraq. The studied heavy metals were iron, copper, chromium, aluminum, cadmium, cobalt, nickel, manganese, zinc and lead. The results obtained in the studied area showed that copper, chromium, cobalt, zinc, manganese, aluminum, iron and lead were within the acceptable limits as recommended by WHO for water drinking. However, in all studied areas, cadmium and nickel were mostly founded to exceed the maximum permissible limit set by WHO. It is found that zinc and copper possess a very good positive correlation between each other. The results obtained in this study confirmed the groundwater pollution and hence it is not suitable for consumption without any prior treatment.
\end{abstract}

KEYWORDS: Zakho City, Water Quality, Heavy metals, Water Pollution, Well Water.

\section{INTRODUCTION}

The global population growth and accelerated industrialization process in combination with agricultural activities has brought the risk of rising the population index is natural environments, for instance air, soil, water, etc. (Assubaie, 2015; Dawson \& Macklin, 1998; Ekpo \& Ibok, 1998; Morrison, Revitt, \& Ellis, 1990). Since of their persistence and accumulation in different environmental compartments, heavy metals are considered as one of the most serious environmental pollutants. More attention has been devoted to the investigation of heavy metal pollutants in the environment because of the increasing anthropogenic contribution by these pollutants (Edmunds, Shand, Hart, \& Ward, 2003; Marengo et al., 2006). The main sources of pollution, which are responsible for producing significant load of heavy metals to the environment, are low efficiency in industrial production processes (petrochemical, energy power plants and chemical industries etc.) and the unsuitable management and handling of industrial wastes (Banat, Howari, \& Al-Hamad, 2005; Charlesworth \& Lees, 1999; Kuang, Neumann, Norra, \& Stüben, 2004; Mireles et al., 2004; Namaghi, Karami, \& Saadat, 2011).

Groundwater is considered as the healthiest drinking water source, but agricultural, domestic and industrial activities led to the degradation of water quality in different parts of the world. In developing countries like Iraq, groundwater pollutants are responsible for waterborne and water related diseases. Since natural filtration through sediments and soils, generally, water supplies from groundwater are free from suspended and organic contaminants (Karanth, 1989). Regional geology, geochemical processes and land use patterns are main factors for controlling the chemistry of groundwater (Kumar, Ramanathan, Rao, \& Kumar, 2006; Liu, Jang, Chen, Lin, \& Lou, 2008; Rajesh, Brindha, Murugan, \& Elango, 2012; Zhu \& Schwartz, 2011).
Availability of groundwater as well as quality is deteriorating at a faster rate in response to developmental activities. Storage and flow of groundwater in hard rock regions have always been a main issue for general public, water managers and researchers either with respect to water quality and water quantity (De Silva \& Weatherhead, 1997; Gupta \& Singh, 1988; Négrel, Lemière, Machard de Grammont, Billaud, \& Sengupta, 2007; Robins \& Smedley, 1994). Also, the limitation of groundwater aquifers and resource and long term sustainability is a major issue (Foster \& Bank, 2002; Singhal, Niwas, \& Singhal, 1988).

The main aim of this study was to assess the quality of well water sources in Zakho City in northern Iraq, Kurdistan Region. With the aid of Atomic Absorption Spectrophotometer (AAS) the presence and concentration of ten heavy metals (Iron, Aluminum, Cadmium, Manganese, Copper, Chrom, Nickel, Zinc, Cobalt and Lead) were determined and the results compared to the maximum contaminant level specified by the World Health Organization (WHO).

\section{MATERIALS AND METHODS}

\subsection{Digestion and Analysis of Water Samples}

Water sample, $100 \mathrm{ml}$ of well mixed acid preserved, was transferred into a beaker and $5 \mathrm{ml}$ of concentrated nitric acid was added. The beaker was placed on a heater and allowed to evaporate to about $5 \mathrm{ml}$ without boiling. Then diluted to $100 \mathrm{ml}$ in a volumetric flask and was ready for analysis. For all water samples, these procedures were adopted for all water samples (Nouri, Mahvi, Jahed, \& Babaei, 2008). Thereafter, metals of interest ( $\mathrm{Mn}, \mathrm{Pb}, \mathrm{Ni}, \mathrm{Cd}, \mathrm{Cu}, \mathrm{Fe}, \mathrm{Al}, \mathrm{Cr}, \mathrm{Co}$ and $\mathrm{Zn}$ ) were assayed using Flam Atomic Absorption Spectrophotometer, Shimadzu AA7000, Japan.

\footnotetext{
* Corresponding author
} 


\subsection{Water sample Collecting and Studied Area}

According to standard procedure by (Clesceri et al., 1998), groundwater samples were collected in January 2013 from 15 different well waters from Zakho City, Duhok Governorate, Kurdistan Region. The sampling locations and coordinates for sampling sites are shown in Table 1. The map of Zakho City and locations of sampling sites are shown in Figure 1.

Table 1. Sampling Locations and GPS Coordinates for sampling

\begin{tabular}{|c|c|c|}
\hline Well ID & \multicolumn{2}{|c|}{ Coordinates } \\
\hline W1 & $37^{\circ} 10^{\prime} 42.36 " \mathrm{~N}$ & $42^{\circ} 48^{\prime} 36.03^{\prime \prime} \mathrm{E}$ \\
\hline W2 & $37^{\circ} 10^{\prime} 1.21 " \mathrm{~N}$ & $42^{\circ} 43^{\prime} 31.82^{\prime \prime E}$ \\
\hline W3 & $37^{\circ} 9^{\prime} 57.00^{\prime \prime} \mathrm{N}$ & $42^{\circ} 43^{\prime} 41.82^{\prime \prime} \mathrm{E}$ \\
\hline W4 & $37^{\circ} 10^{\prime} 1.51 " \mathrm{~N}$ & $42^{\circ} 43^{\prime} 12.83^{\prime \prime E}$ \\
\hline W5 & $37^{\circ} 8^{\prime} 30.14^{\prime \prime N}$ & $42^{\circ} 34^{\prime} 35.93^{\prime \prime} \mathrm{E}$ \\
\hline W6 & $37^{\circ} 829.43 " \mathrm{~N}$ & $42^{\circ} 34^{\prime} 21.01 " \mathrm{E}$ \\
\hline W7 & $37^{\circ} 9^{\prime} 24.07^{\prime \prime N}$ & $42^{\circ} 41^{\prime} 32.14^{\prime \prime} \mathrm{E}$ \\
\hline W8 & $37^{\circ} 8^{\prime} 15.23 " \mathrm{~N}$ & $42^{\circ} 41^{\prime} 17.53 " \mathrm{E}$ \\
\hline W9 & $37^{\circ} 9^{\prime} 42.55 " \mathrm{~N}$ & $42^{\circ} 40^{\prime} 41.03^{\prime \prime} \mathrm{E}$ \\
\hline W10 & $37^{\circ} 9^{\prime} 25.35^{\prime \prime N}$ & $42^{\circ} 40^{\prime} 6.40^{\prime \prime} \mathrm{E}$ \\
\hline W11 & $37^{\circ} 14^{\prime} 30.90^{\prime \prime} \mathrm{N}$ & $43^{\circ} 9^{\prime} 46.65 " \mathrm{E}$ \\
\hline W12 & $37^{\circ} 14^{\prime} 20.06^{\prime \prime N}$ & $43^{\circ} 9^{\prime} 43.23^{\prime \prime E}$ \\
\hline W13 & $37^{\circ} 14^{\prime} 4.57^{\prime \prime N}$ & $43^{\circ} 9^{\prime} 43.81^{\prime \prime E}$ \\
\hline W14 & $37^{\circ} 07^{\prime} 51.3^{\prime \prime N}$ & $42^{\circ} 53^{\prime} 37.5^{\prime \prime E}$ \\
\hline W15 & $37^{\circ} 11^{\prime} 29.5 \mathrm{~N} \mathrm{~N}$ & $42^{\circ} 51^{\prime} 12.6^{\prime \prime} \mathrm{E}$ \\
\hline
\end{tabular}

Table 2. Physical and chemical properties of water samples from the selected sites

\begin{tabular}{|c|c|c|c|c|c|c|c|c|c|c|c|c|c|c|c|c|}
\hline Parameters & WHO & W1 & W2 & W3 & W4 & W5 & W6 & W7 & W8 & W9 & W10 & W11 & W12 & W13 & W14 & W15 \\
\hline Turb. (NTU) & 5 & 0.3 & 0.4 & 0.2 & 0.5 & 0.2 & 0.4 & 0.3 & 0.1 & 0.2 & 0.2 & 0.4 & 0.2 & 19.7 & 0.8 & 0.6 \\
\hline pH & $6.5-8.5$ & 7.48 & 7.87 & 7.97 & 8.08 & 7.86 & 8.02 & 8.08 & 8.15 & 8.06 & 8.11 & 7.94 & 8.06 & 8.88 & 8.07 & 8.43 \\
\hline $\mathrm{EC}(\mu \mathrm{s} / \mathrm{cm})$ & & 600 & 556 & 468 & 498 & 649 & 496 & 517 & 471 & 574 & 659 & 615 & 562 & 479 & 551 & 800 \\
\hline TDS (mg/L) & 1000 & 384 & 355 & 299 & 319 & 415 & 317 & 331 & 301 & 367 & 422 & 393 & 359 & 307 & 353 & 512 \\
\hline $\mathrm{NO}_{3}{ }^{-1}(\mathrm{mg} / \mathrm{L})$ & 50 & 44.7 & 42.4 & 19.9 & 27.6 & 40.4 & 28.4 & 36.3 & 29.5 & 54.7 & 74.4 & 2.44 & 7.58 & 2.92 & 17.7 & 2.26 \\
\hline TAI (mg/L) & $125-200$ & 274 & 292 & 270 & 282 & 330 & 278 & 268 & 270 & 280 & 296 & 334 & 306 & 282 & 334 & 508 \\
\hline TH (mg/L) & $100-500$ & 324 & 372 & 304 & 324 & 412 & 316 & 328 & 300 & 356 & 388 & 392 & 332 & 340 & 380 & 544 \\
\hline $\mathrm{Ca}^{+2}(\mathrm{mg} / \mathrm{L})$ & $75-200$ & 83.2 & 94.4 & 76.8 & 83.2 & 110 & 78.4 & 83.2 & 76.8 & 91.2 & 99.2 & 96 & 92.8 & 59.2 & 70.4 & 84.8 \\
\hline $\mathrm{Mg}^{+2}(\mathrm{mg} / \mathrm{L})$ & $30-150$ & 28.3 & 33.1 & 27.3 & 28.3 & 33.1 & 29.2 & 29.2 & 26.3 & 31.2 & 34.1 & 37.0 & 24.4 & 46.8 & 49.7 & 81.0 \\
\hline $\mathrm{Cl}^{-}(\mathrm{mg} / \mathrm{L})$ & 250 & 18 & 26 & 20 & 22 & 40 & 30 & 28 & 26 & 36 & 46 & 24 & 20 & 12 & 20 & 18 \\
\hline $\mathrm{Na}^{+}(\mathrm{mg} / \mathrm{L})$ & 200 & 12 & 11 & 10 & 10.3 & 16.5 & 12 & 10 & 6.5 & 17 & 20 & 4.8 & 13.5 & 3 & 11.3 & 22 \\
\hline $\mathbf{K}^{+}(\mathbf{m g} / \mathbf{L})$ & $2-3$ & 1 & 2 & 2 & 2 & 3 & 2 & 2 & 2 & 2 & 2 & 1 & 1 & 1 & 2 & 2 \\
\hline $\mathrm{SO}_{4}{ }^{-2}(\mathrm{mg} / \mathrm{L})$ & 250 & 9 & 14 & 4 & 9 & 23 & 9 & 8 & 8 & 14 & 19 & 46 & 22 & 29 & 2 & 29 \\
\hline
\end{tabular}

The results obtained for the metal ion concentrations $(\mathrm{Mn}, \mathrm{Pb}, \mathrm{Ni}$, $\mathrm{Co}, \mathrm{Cd}, \mathrm{Cu}, \mathrm{Fe}, \mathrm{Al}, \mathrm{Cr}$ and $\mathrm{Zn}$ ) in the water samples collected from various sites was compared with the maximum permissible limit of WHO. The physical and chemical properties of water samples from the selected sites is shown in Table 2. The concentrations for analyzed metals are summarized in Table 3.

The maximum tolerance limit by WHO for iron, copper, manganese and zinc are $0.2,1,0.5$ and $4 \mathrm{mg} / \mathrm{L}$, respectively. As shown in Table 3, these metals in all well water samples were observed to be below the maximum permissible limit set by WHO. Although these metals are considered as an essential nutrient, but at high doses they have been reported to cause damage to the kidneys and can become fatal, as well as, they may cause a decrease in fetal growth (Cassat \& Skaar; Mattison et al.; Olmedo et al., 2013; Salgueiro et al., 2000; Schaible \& Kaufmann, 2004).

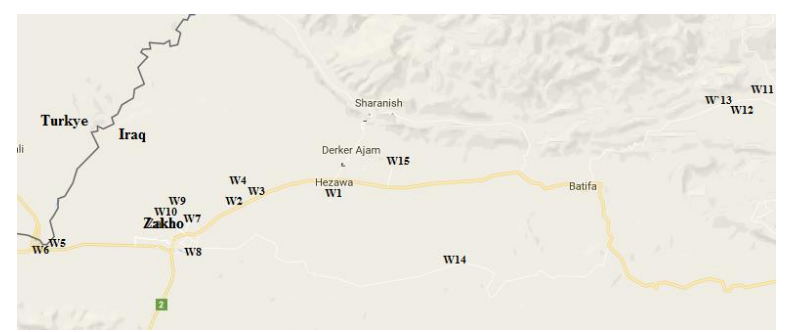

Figure 1. Map of Zakho City showing the locations of sampling sites. 
Lead is considered as the most significant toxin of the heavy metals, and the inorganic forms are absorbed through ingestion by food and water, and inhalation (Jaishankar, Tseten, Anbalagan, Mathew, \& Beeregowda, 2014). The permissible limit of $\mathrm{Pb}$ concentrations by WHO for drinking water. The maximum concentration found to be 0.00153 $\mathrm{mg} / \mathrm{L}$ in $\mathrm{W} 1$ for $\mathrm{Pb}$.

The permissible limit of $\mathrm{Co}, \mathrm{Al}$ and $\mathrm{Cr}$ concentrations by WHO are $0.005,0.2$ and $0.05 \mathrm{mg} / \mathrm{L}$, respectively. As shown in Table 3, Co, $\mathrm{Al}$ and $\mathrm{Cr}$ ions in all samples were observed to be below the maximum permissible limit set by WHO for drinking water except in well W5, in which the level of Co and $\mathrm{Cr}$ were $0.00705,0.350$ and $0.0614 \mathrm{mg} / \mathrm{L}$, respectively. It has been reported that metals such as cobalt (Co) and chromium $(\mathrm{Cr})$ are essential nutrients that are required for various biochemical and physiological functions; however, these elements, at high doses, are considered to be toxic industrial pollutant that is classified as human carcinogen by several regulatory and non-regulatory agencies (Tchounwou, Yedjou, Patlolla, \& Sutton, 2012).

At extremely low levels, $\mathrm{Cd}$ is a toxic and non-essential heavy metal and high exposure can cause obstructive lung disease (Khaled et al.). The maximum allowable concentration of $\mathrm{Cd}$ by WHO is $0.003 \mathrm{mg} / \mathrm{L}$. It was found that Cd concentration in all wells was above the acceptable concentration set by WHO for drinking water. The maximum concentration for $\mathrm{Cd}$ found to be 0.089 and $0.085 \mathrm{mg} / \mathrm{L}$ in $\mathrm{W} 6$ and $w 5$, respectively.

Table 3. Concentration of metals ion in five different sites compared to WHO for drinking water.

\begin{tabular}{|c|c|c|c|c|c|c|c|c|c|c|}
\hline Well ID & Fe (mg/L) & $\mathrm{Cu}(\mathrm{mg} / \mathrm{L})$ & Mn (mg/L) & $\overline{Z n}(\mathrm{mg} / \mathrm{L})$ & Co $(\mathrm{mg} / \mathrm{L})$ & $\mathrm{Ni}(\mathrm{mg} / \mathrm{L})$ & $\mathrm{Pb}(\mathrm{mg} / \mathrm{L})$ & $\mathrm{Cd}(\mathrm{mg} / \mathrm{L})$ & $\mathrm{Cr}(\mathrm{mg} / \mathrm{L})$ & $\overline{\mathrm{Al}}(\mathrm{mg} / \mathrm{L})$ \\
\hline WHO & 0.2 & 1 & 0.5 & 4 & 0.005 & 0.02 & 0.01 & 0.003 & 0.05 & 0.2 \\
\hline W1 & 0.0096 & 0.01096 & 0.0009842 & 0.0240000 & 0.0000533 & 0.0454150 & 0.0015357 & 0.0055638 & 0.0088144 & 0.0559242 \\
\hline W2 & 0.0044 & 0.0322 & 0.0002314 & 0.0009000 & 0.0000022 & 0.0277000 & 0.0000000 & 0.0059000 & 0.0185000 & 0.0107415 \\
\hline W3 & 0.0087 & 0.029 & 0.0018922 & 0.0073000 & 0.0001035 & 0.0277000 & 0.0000000 & 0.0076000 & 0.0214000 & 0.0099024 \\
\hline W4 & 0.0277 & 0.0322 & 0.0001000 & 0.0769000 & 0.0000668 & 0.0323000 & 0.0000000 & 0.0072000 & 0.0204000 & 0.0155855 \\
\hline W5 & 0.0321 & 0.0322 & 0.0000160 & 0.0132000 & 0.0070517 & 0.0693000 & 0.0000000 & 0.0085000 & 0.0614000 & 0.3506665 \\
\hline W6 & 0.0131 & 0.0387 & 0.000200 & 0.0082000 & 0.0000000 & 0.0416000 & 0.0000000 & 0.0089000 & 0.0156000 & 0.0308656 \\
\hline W7 & 0.0233 & 0.0226 & 0.0005312 & 0.0450000 & 0.0000000 & 0.0139000 & 0.0000000 & 0.0051000 & 0.0195000 & 0.0147340 \\
\hline W8 & 0.0175 & 0.0258 & 0.0002404 & 0.0043000 & 0.0000603 & 0.0300000 & 0.0000000 & 0.0055000 & 0.0224000 & 0.0151182 \\
\hline W9 & 0.0335 & 0.0258 & 0.0007109 & 0.0039000 & 0.0000108 & 0.0323000 & 0.0000000 & 0.0051000 & 0.0214000 & 0.0278475 \\
\hline W10 & 0.0292 & 0.0322 & 0.0003000 & 0.0006000 & 0.0003158 & 0.0346000 & 0.0000000 & 0.0059000 & 0.0234000 & 0.0122277 \\
\hline W11 & 0.0350 & 0.0258 & 0.0005322 & 0.0026000 & 0.0000409 & 0.0231000 & 0.0000000 & 0.0068000 & 0.0195000 & 0.0237992 \\
\hline W12 & 0.03210 & 0.0258 & 0.0004000 & 0.0099000 & 0.0000776 & 0.0323000 & 0.0000000 & 0.0076000 & 0.0214000 & 0.0072117 \\
\hline W13 & 0.12530 & 0.0548 & 0.0009591 & 0.0078000 & 0.0000474 & 0.0277000 & 0.0000000 & 0.0080000 & 0.0195000 & 0.0153915 \\
\hline W14 & 0.08975 & 0.0580 & 0.0004657 & 1.3066000 & 0.0000108 & 0.0208000 & 0.0013065 & 0.0055000 & 0.0097000 & 0.0160974 \\
\hline W15 & 0.170 & 0.0226 & 0.0026199 & 0.054500 & 0.0000108 & 0.0139000 & 0.0000000 & 0.0051000 & 0.0078000 & 0.0180394 \\
\hline
\end{tabular}

Table 4. Correlation matrix among different heavy metals in water wells of Zakho City.

\begin{tabular}{|c|c|c|c|c|c|c|c|c|c|c|}
\hline & $\mathbf{F e}$ & $\mathrm{Cu}$ & Mn & Zn & Co & $\mathbf{N i}$ & $\mathbf{P b}$ & Cd & $\mathrm{Cr}$ & Al \\
\hline $\mathbf{F e}$ & 1 & & & & & & & & & \\
\hline $\mathrm{Cu}$ & 0.411 & 1 & & & & & & & & \\
\hline Mn & -0.102 & -0.189 & 1 & & & & & & & \\
\hline $\mathbf{Z n}$ & -0.245 & 0.617 & -0.038 & 1 & & & & & & \\
\hline Co & 0.096 & -0.046 & -0.178 & -0.168 & 1 & & & & & \\
\hline $\mathrm{Ni}$ & 0.067 & -0.082 & -0.429 & -0.225 & 0.165 & 1 & & & & \\
\hline $\mathbf{P b}$ & -0.280 & 0.045 & 0.071 & 0.605 & -0.118 & 0.077 & 1 & & & \\
\hline Cd & 0.380 & 0.333 & -0.279 & -0.216 & 0.032 & 0.543 & -0.311 & 1 & & \\
\hline $\mathrm{Cr}$ & 0.369 & -0.01 & -0.491 & -0.462 & 0.418 & 0.207 & -0.693 & 0.307 & 1 & \\
\hline Al & -0.126 & -0.380 & 0.097 & -0.084 & -0.215 & 0.298 & 0.616 & -0.135 & -0.525 & 1 \\
\hline
\end{tabular}

Nickel represents a good example of a metal whose use is widening in modern technologies. As the result of accelerated consumption of nickel-containing products nickel compounds are released to the environment at all stages of production and utilization. Their accumulation in the environment may represent a serious hazard to human health. Among the known health related effects of nickel are skin allergies, lung fibrosis, variable degrees of kidney and cardiovascular system poisoning and stimulation of neoplastic transformation (Denkhaus \& Salnikow, 2002). The maximum acceptable concentrations set by WHO is 0.02 $\mathrm{mg} / \mathrm{L}$ for Ni ions. As shown in Table 3, Al metal ion in all wells, except W 7 and W 15, was observed to be above the maximum permissible limit set by the WHO for drinking water. The maximum concentrations of $\mathrm{Ni}$ found to be 0.0693 $\mathrm{mg} / \mathrm{L}$.

To measure and establish the relationship between two variables, the correlation coefficient is commonly used. It is a statistical tool to show the dependency degree of one variable to the other (Stigler, 1989). The correlation matrix of analyzed metals has been represented in Table 4. As shown, copper ion metal exhibit high positive correlation with $\mathrm{Zn}(\mathrm{r}=0.6174)$. However, $\mathrm{Zn}$ exhibit high correlation with $\mathrm{Pb}(\mathrm{r}=0.6055)$ and $\mathrm{Pb}$ metal exhibit high correlation with $\mathrm{Al}$ metal $(\mathrm{r}=0.6168)$. Nickel ion exhibit high positive correlation with $\mathrm{Cd}(\mathrm{r}=0.5434) . \mathrm{Cu}$ and $\mathrm{Zn}$ possess a very good positive correlation $(r=0.6174)$ between each other. According to the results shown in this investigation, the water 
from well in Zakho City is not suitable for consumption without any prior treatment.

\section{CONCLUSION}

The results obtained in the studied area of Zakho City well water showed that iron, copper, zinc, manganese and lead were within the acceptable limits according to WHO for water drinking. However, chromium, cobalt and aluminum were mostly founded, at some studied area, to exceed the maximum permissible limit as recommended by WHO. Cadmium and nickel, in all well water in Zakho City found to be above the maximum permissible set by WHO. It is also found that $\mathrm{Cu}$ and $\mathrm{Zn}$ possess a very good positive correlation between each other. Rock mineral dissolution with the groundwater is a possible reason for contamination. The results obtained in this study confirmed the high groundwater pollution and hence it is not suitable for consumption without any prior treatment.

\section{REFERENCES}

Assubaie, F. N. (2015). Assessment of the levels of some heavy metals in water in Alahsa Oasis farms, Saudi Arabia, with analysis by atomic absorption spectrophotometry. Arabian Journal of Chemistry, 8(2), 240-245. doi: http://dx.doi.org/10.1016/j.arabjc.2011.08.018

Banat, K. M., Howari, F. M., \& Al-Hamad, A. A. (2005). Heavy metals in urban soils of central Jordan: Should we worry about their environmental risks? Environmental Research, 97(3), 258-273. doi: http://dx.doi.org/10.1016/j.envres.2004.07.002

Cassat, James E., \& Skaar, Eric P. Iron in Infection and Immunity. Cell Host \& Microbe, 13(5), 509-519. doi: 10.1016/j.chom.2013.04.010

Charlesworth, S. M., \& Lees, J. A. (1999). The distribution of heavy metals in deposited urban dusts and sediments, Coventry, England. Environmental Geochemistry and Health, 21(2), 97-115. doi: 10.1023/A:1006694400288

Clesceri, L. S., Eaton, A. D., Greenberg, A. E., Association, A. P. H., Association, A. W. W., \& Federation, W. E. (1998). Standard Methods for the Examination of Water and Wastewater: American Public Health Association.

Dawson, E. J., \& Macklin, M. G. (1998). Speciation of Heavy Metals in Floodplain and Flood Sediments: a Reconnaissance Survey of the Aire Valley, West Yorkshire, Great Britain. Environmental Geochemistry and Health, 20(2), 67-76. doi: $10.1023 / \mathrm{A}: 1006541724394$

De Silva, C. S., \& Weatherhead, E. K. (1997). Optimising the dimensions of agrowells in hard-rock aquifers in Sri Lanka. Agricultural Water Management, 33(2), 117-126. doi: http://dx.doi.org/10.1016/S0378-3774(96)01297-8

Denkhaus, E., \& Salnikow, K. (2002). Nickel essentiality, toxicity, and carcinogenicity. Critical Reviews in Oncology/Hematology, 42(1), 35-56. doi: http://dx.doi.org/10.1016/S1040-8428(01)00214-1

Edmunds, W. M., Shand, P., Hart, P., \& Ward, R. S. (2003). The natural (baseline) quality of groundwater: a UK pilot study. Science of The Total Environment, 310(1-3), 2535. doi: http://dx.doi.org/10.1016/S00489697(02)00620-4

Ekpo, B. O., \& Ibok, U. J. (1998). Seasonal variation and partition of trace metals $(\mathrm{Fe}, \mathrm{Zn}, \mathrm{Cu}, \mathrm{Mn}, \mathrm{Cr}, \mathrm{Cd}$ and $\mathrm{Pb})$ in surface sediments: relationship with physico-chemical variables of water from the Calabar River, South Eastern Nigeria. Environmental Geochemistry and Health, 20(3), 113121. doi: 10.1023/A:1006528324687

Foster, S. S. D., \& Bank, W. (2002). Groundwater Quality Protection: A Guide for Water Utilities, Municipal Authorities, and Environment Agencies: World Bank.

Gupta, C. P., \& Singh, V. S. (1988). Flow regime associated with partially penetrating large-diameter wells in hard rocks. Journal of Hydrology, 103(3), 209-217. doi: http://dx.doi.org/10.1016/0022-1694(88)90134-5
Jaishankar, M., Tseten, T., Anbalagan, N., Mathew, B. B., \& Beeregowda, K. N. (2014). Toxicity, mechanism and health effects of some heavy metals. Interdisciplinary Toxicology, 7(2), 60-72. doi: 10.2478/intox-2014-0009

Karanth, K. R. (1989). Hydrogeology: Tata McGraw-Hill Publishing Company.

Khaled, B., Wided, B., Béchir, H., Elimame, E., Mouna, L., \& Zied, T. Investigation of electrocoagulation reactor design parameters effect on the removal of cadmium from synthetic and phosphate industrial wastewater. Arabian Journal of Chemistry.

http://dx.doi.org/10.1016/j.arabjc.2014.12.012

Kuang, C., Neumann, T., Norra, S., \& Stüben, D. (2004). Land Userelated Chemical Composition of Street Sediments in Beijing. Environmental Science and Pollution Research, 11(2), 73. doi: 10.1007/BF02979706

Kumar, M., Ramanathan, A. L., Rao, M. S., \& Kumar, B. (2006). Identification and evaluation of hydrogeochemical processes in the groundwater environment of Delhi, India. Environmental Geology, 50(7), 1025-1039. doi: 10.1007/s00254-006-0275-4

Liu, C.-W., Jang, C.-S., Chen, C.-P., Lin, C.-N., \& Lou, K.-L. (2008) Characterization of groundwater quality in Kinmen Island using multivariate analysis and geochemical modelling. Hydrological Processes, 22(3), 376-383. doi: 10.1002/hyp.6606

Marengo, E., Gennaro, M. C., Robotti, E., Rossanigo, P., Rinaudo, C., \& Roz-Gastaldi, M. (2006). Investigation of anthropic effects connected with metal ions concentration, organic matter and grain size in Bormida river sediments. Analytica Chimica Acta, $\quad 560(1-2), \quad 172-183$. doi: http://dx.doi.org/10.1016/j.aca.2005.11.086

Mattison, D. R., Milton, B., Krewski, D., Levy, L., Dorman, D. C., Aggett, P. J., . . McGough, D. Severity scoring of manganese health effects for categorical regression. NeuroToxicology. doi: http://dx.doi.org/10.1016/j.neuro.2016.09.001

Mireles, A., Solís, C., Andrade, E., Lagunas-Solar, M., Piña, C., \& Flocchini, R. G. (2004). Heavy metal accumulation in plants and soil irrigated with wastewater from Mexico city. Nuclear Instruments and Methods in Physics Research Section B: Beam Interactions with Materials and Atoms, 219-220, 187190. doi: http://dx.doi.org/10.1016/j.nimb.2004.01.051

Morrison, G. M. P., Revitt, D. M., \& Ellis, J. B. (1990). Metal Speciation in Separate Stormwater Systems. Water Science and Technology, 22(10-11), 53-60.

Namaghi, H. H., Karami, G. H., \& Saadat, S. (2011). A study on chemical properties of groundwater and soil in ophiolitic rocks in Firuzabad, east of Shahrood, Iran: with emphasis to heavy metal contamination. Environmental Monitoring and Assessment, 174(1), 573-583. doi: 10.1007/s10661-010-14793

Négrel, P., Lemière, B., Machard de Grammont, H., Billaud, P., \& Sengupta, B. (2007). Hydrogeochemical processes, mixing and isotope tracing in hard rock aquifers and surface waters from the Subarnarekha River Basin, (east Singhbhum District, Jharkhand State, India). Hydrogeology Journal, 15(8), 1535 1552. doi: 10.1007/s10040-007-0227-4

Nouri, J., Mahvi, A. H., Jahed, G. R., \& Babaei, A. A. (2008). Regional distribution pattern of groundwater heavy metals resulting from agricultural activities. Environmental Geology, 55(6), 1337-1343. doi: 10.1007/s00254-007-1081-3

Olmedo, P., Hernández, A. F., Pla, A., Femia, P., Navas-Acien, A., \& Gil, F. (2013). Determination of essential elements (copper, manganese, selenium and zinc) in fish and shellfish samples. Risk and nutritional assessment and mercury-selenium balance. Food and Chemical Toxicology, 62, 299-307. doi: http://dx.doi.org/10.1016/j.fct.2013.08.076

Rajesh, R., Brindha, K., Murugan, R., \& Elango, L. (2012). Influence of hydrogeochemical processes on temporal changes in groundwater quality in a part of Nalgonda district, Andhra Pradesh, India. Environmental Earth Sciences, 65(4), 1203 1213. doi: 10.1007/s12665-011-1368-2

Robins, N. S., \& Smedley, P. L. (1994). Hydrogeology and hydrogeochemistry of a small, hard-rock island - the heavily stressed aquifer of Jersey. Journal of Hydrology, 163(3), 249269. doi: http://dx.doi.org/10.1016/0022-1694(94)90143-0

Salgueiro, M. J., Zubillaga, M., Lysionek, A., Sarabia, M. I., Caro, R., De Paoli, T., . . . Boccio, J. (2000). Zinc as an essential 
micronutrient: A review. Nutrition Research, 20(5), 737755. doi: http://dx.doi.org/10.1016/S0271 5317(00)00163-9

Schaible, U. E., \& Kaufmann, S. H. E. (2004). Iron and microbial infection. Nat Rev Micro, 2(12), 946-953.

Singhal, D. C., Niwas, S., \& Singhal, B. B. S. (1988). Integrated approach to aquifer delineation in hard rock terrains - A case study from the Banda District, India. Journal of Hydrology, $\quad$ 98(1), 165-183. doi: http://dx.doi.org/10.1016/0022-1694(88)90212-0
Stigler, S. M. (1989). Francis Galton's Account of the Invention of Correlation. Statistical Science, 4(2), 73-79.

Tchounwou, P. B., Yedjou, C. G., Patlolla, A. K., \& Sutton, D. J. (2012). Heavy Metals Toxicity and the Environment. EXS, 101, 133164. doi: 10.1007/978-3-7643-8340-4_6

Zhu, C., \& Schwartz, F. W. (2011). Hydrogeochemical Processes and Controls on Water Quality and Water Management. Elements, 7(3), 169-174. doi: 10.2113/gselements.7.3.169.

كورتيا ليّكولينى:

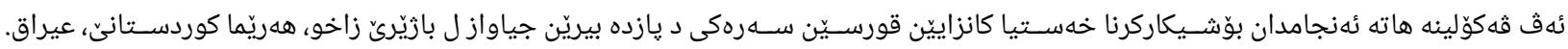

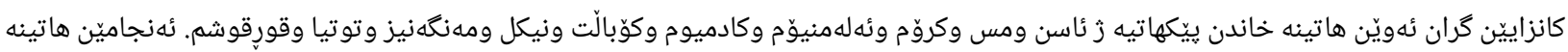

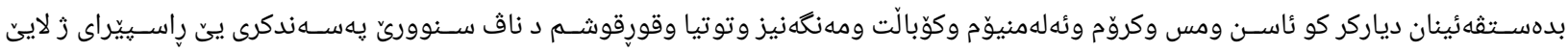

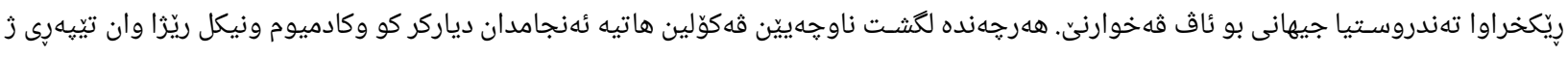

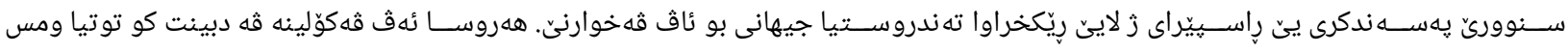

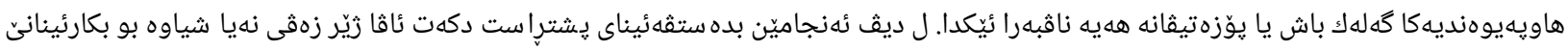
بـ جارهسهريا يِيشتر.

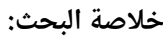
أجريت هذه الدراسة لفحص تركيزات المعادن الثقيلة الاساسية في خمسة عشر بئر ماء مختلفة في مدينة زاخو، إقليم كوردستان، العراق. المعادن الثقيلة

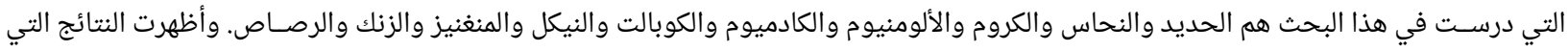

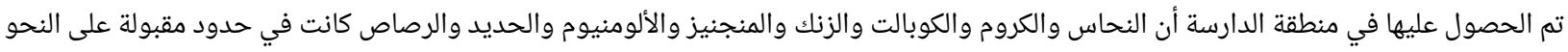

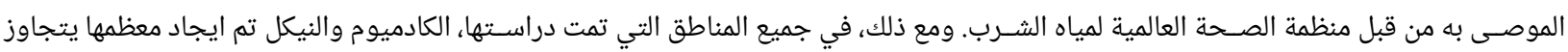

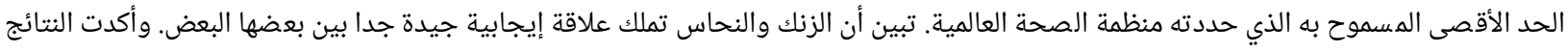

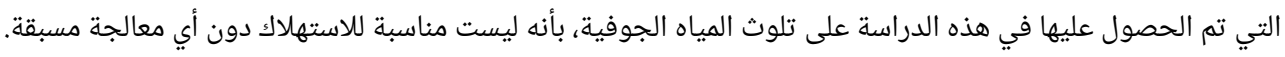

